\title{
Gold price volatility, tax revenue, and employment: can Burkina Faso's adaptation strategy avoid the natural resource curse? - CORRIGENDUM
}

Delphine Carole Sisso and Olivier Beaumais

https://doi.org/10.1017/S1355770X18000037 Published online by Cambridge University Press, 27

February 2018

Keywords: CGE; labor market; mining boom; resource curse; tax reform; corrigendum

In the recent publication mentioned above, the authors would like to apologise for a failure to acknowledge financial and scientific support from the Partnership for Economic Policy (PEP), as well as funding from the Department for International Development (DFID) of the United Kingdom (or UK Aid), and the Government of Canada through the International Development Research Centre (IDRC).

\section{Reference}

Sisso DC and Beaumais O (2018) Gold price volatility, tax revenue, and employment: can Burkina Faso's adaptation strategy avoid the natural resource curse? Environment and Development Economics, 1-15. doi:10.1017/S1355770X18000037. 